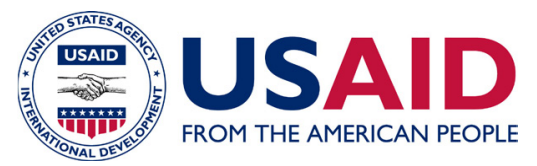

\title{
Documentation for Initial Seismic Hazard Maps for Haiti
}

By Arthur Frankel, Stephen Harmsen, Charles Mueller, Eric Calais, and Jennifer Haase

Open-File Report 2010-1067 
This page intentionally left blank 


\section{Documentation for Initial Seismic Hazard Maps for Haiti}

By Arthur Frankel, Stephen Harmsen, Charles Mueller, Eric Calais, and Jennifer Haase

Open-File Report 2010-1067 


\section{U.S. Department of the Interior \\ KEN SALAZAR, Secretary \\ U.S. Geological Survey \\ Marcia K. McNutt, Director}

\section{U.S. Geological Survey, Reston, Virginia: 2010}

This report and any updates to it are available online at: http://pubs.usgs.gov/ofr/2010/1067/

For more information on the USGS - the Federal source for science about the Earth, its natural and living resources, natural hazards, and the environment, visit http://www.usgs.gov or call 1-888-ASK-USGS

For an overview of USGS information products, including maps, imagery, and publications, visit http://www.usgs.gov/pubprod

To order this and other USGS information products, visit http://store.usgs.gov

Any use of trade, product, or firm names is for descriptive purposes only and does not imply endorsement by the U.S. Government.

Although this report is in the public domain, permission must be secured from the individual copyright owners to reproduce any copyrighted materials contained within this report.

Suggested citation:

Frankel, Arthur, Harmsen, Stephen, Mueller, Charles, Calais, Eric, and Haase, Jennifer, 2010, Documentation for initial seismic hazard maps for Haiti: U.S. Geological Survey Open-File Report 2010-1067, 12 p. 


\section{Contents}

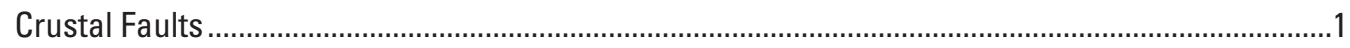

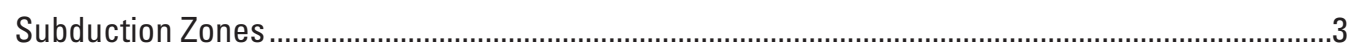

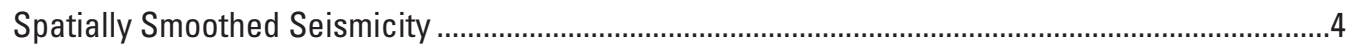

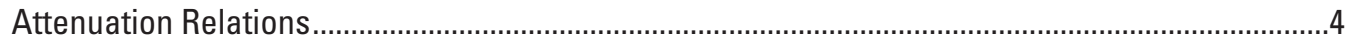

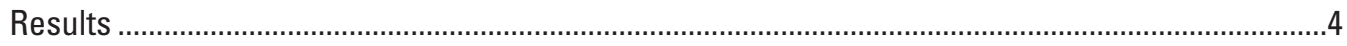

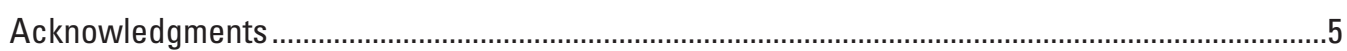

References Cited.

\section{Figures}

1. Seismicity for the Hispaniola region for the time period 1900-2010 ............................................7

2. Crustal faults and subduction zones used in the hazard maps ...............................................

3. Seismic hazard map with peak ground acceleration (PGA; in \%g) having 10 percent probability of exceedance in 50 years without aftershock hazard............................................9

4. Seismic hazard map with PGA $(\% g)$ having 2 percent probability of exceedance in 50 years (1 in 2,500 annual probability of exceedance), without aftershock hazard ..................10

5. Map of Hispaniola showing shear-wave velocity averaged over the top $30 \mathrm{~m}$ of the ground (Vs30) derived from topographic slope ..........................................................11

6. Seismic hazard maps using site amplification based on Vs30 grid in figure 5..........................12

\section{Tables}

1. Parameters for crustal faults and subduction zones, Hispaniola region...................................... 
This page intentionally left blank 


\title{
Documentation for Initial Seismic Hazard Maps for Haiti
}

\author{
By Arthur Frankel', Stephen Harmsen², Charles Mueller ${ }^{2}$, Eric Calais ${ }^{3}$, and Jennifer Haase ${ }^{3}$
}

\section{Introduction}

In response to the urgent need for earthquake-hazard information after the tragic disaster caused by the moment magnitude $(M) 7.0$ January 12, 2010, earthquake, we have constructed initial probabilistic seismic hazard maps for Haiti. These maps are based on the current information we have on fault slip rates and historical and instrumental seismicity. These initial maps will be revised and improved as more data become available. In the short term, more extensive logic trees will be developed to better capture the uncertainty in key parameters. In the longer term, we will incorporate new information on fault parameters and previous large earthquakes obtained from geologic fieldwork. These seismic hazard maps are important for the management of the current crisis and the development of building codes and standards for the rebuilding effort.

The boundary between the Caribbean and North American Plates in the Hispaniola region is a complex zone of deformation (Mann and others, 1984). The highly oblique $\sim 20 \mathrm{~mm} / \mathrm{yr}$ convergence between the two plates (DeMets and others, 2000) is partitioned between subduction zones off of the northern and southeastern coasts of Hispaniola and strikeslip faults that transect the northern and southern portions of the island. There are also thrust faults within the island that reflect the compressional component of motion caused by the geometry of the plate boundary.

We follow the general methodology developed for the 1996 U.S. national seismic hazard maps and also as implemented in the 2002 and 2008 updates (Frankel and others, 2000; Frankel and others, 2002; Petersen and others, 2008). This procedure consists of adding the seismic hazard calculated from crustal faults, subduction zones, and spatially smoothed seismicity for shallow earthquakes and WadatiBenioff-zone earthquakes. Each one of these source classes will be described below. The lack of information on faults in Haiti requires many assumptions to be made. These assumptions will need to be revisited and reevaluated as more fieldwork and research are accomplished.

${ }^{1}$ U.S. Geological Survey, Seattle, WA 98195, afrankel@usgs.gov.

${ }^{2}$ U.S. Geological Survey, Denver, CO 80225, harmsen@usgs.gov, cmueller@usgs.gov.

${ }^{3}$ Purdue University, Department of Earth and Atmospheric Sciences, West Lafayette, IN 47907, ecalais@purdue.edu, jhaase@purdue.edu.
We made two sets of maps using different assumptions about site conditions. One set of maps is for a firm-rock site condition (30-m averaged shear-wave velocity, Vs30, of $760 \mathrm{~m} / \mathrm{s}$ ). We also developed hazard maps that contain site amplification based on a grid of Vs30 values estimated from topographic slope (Wald and Allen, 2007). These maps take into account amplification from soils.

We stress that these new maps are designed to quantify the hazard for Haiti; they do not consider all the sources of earthquake hazard that affect the Dominican Republic and therefore should not be considered as complete hazard maps for eastern Hispaniola. For example, we have not included hazard from earthquakes in the Mona Passage nor from large earthquakes on the subduction zone interface north of Puerto Rico. Furthermore, they do not capture all the earthquake hazards for eastern Cuba.

Figure 1 shows the seismicity catalog that we developed for this study. This catalog was compiled from three data sources: (1) the U.S. Geological Survey (USGS) PDE catalog from 1973 to the present, (2) the Engdahl and Villasenor (2002) catalog, and (3) the International Seismic Centre (ISC) catalog. Dependent events (for example, aftershocks and foreshocks) were removed from the catalog, following the declustering procedure outlined in Mueller and others (1997). The seismicity catalog shows more earthquakes of $M 4$ and greater in the eastern portion of Hispaniola (the Dominican Republic) than in Haiti. However, there have been several destructive large earthquakes in Haiti since the 1600s (see Kelleher and others, 1973; McCann, 2006; Ali and others, 2008).

\section{Crustal Faults}

The fault traces used for this study are depicted in figure 2. These traces were compiled from the geological and geophysical literature on offshore and onshore active faults in the northeastern Caribbean. Three crustal faults were included in the hazard calculation: the Enriquillo, Septentrional, and Matheux Neiba Faults. To our knowledge, the first two of these faults are the only crustal faults in Haiti that have slip-rate estimates derived from data. The slip rate for the Septentrional Fault is constrained by geologic mapping (Prentice and others, 2003) and global positioning system (GPS) measurements; the slip rate for the Enriquillo fault is 
only estimated from GPS measurements (Calais and others, 2002; Manaker and others, 2008).

For each fault, we applied a frequency-magnitude distribution to account for the random uncertainty in the magnitude of future earthquakes. We follow a procedure similar to that used in the 1996, 2002, and 2008 versions of the U.S. national seismic hazard maps. First the seismic moment rate of each fault segment was calculated from its estimated slip rate, segment length, and width. The maximum magnitude of rupture (denoted here as $M_{\text {char }}$ or $M_{\max }$ ) for each segment was determined from the segment length and the empirical relation between surface rupture length and moment magnitude from Wells and Coppersmith (1994). For the Enriquillo and Matheux Neiba Faults, the frequencymagnitude distribution was formed by assigning 50 percent of the seismic moment rate to earthquakes that rupture the entire fault segment producing earthquakes with magnitude around $\mathrm{M}_{\text {char }}$ and 50 percent of the moment release to earthquakes that follow a truncated Gutenberg-Richter (GR; exponential) recurrence model with minimum magnitude of 6.5 and maximum magnitude equal to $M_{\text {char }} \mathrm{A} b$-value of 1 was used for the GR portion of the distribution for all the faults and subduction zones.

We found that extending the GR relation to magnitudes less than 6.5 predicts more $M 5$ earthquakes than have been observed on the crustal faults. We used the spatially smoothed gridded seismicity to capture the hazard from random earthquakes between M5.0 and 7.0 (see section on Spatially Smoothed Seismicity).

We included aleatory and epistemic uncertainties for the estimates of $M_{\text {char }}$ in the same manner as in the 2002 and 2008 U.S. national seismic hazard maps (Frankel and others, 2002; Petersen and others, 2008). The Haiti hazard maps are produced from the mean hazard curves. The slip rates, magnitude ranges, and predicted seismicity rates for all the sources are compiled in table 1. For the Enriquillo and Septentrional Faults, the predicted earthquake rates in table 1 are for the portion of the faults shown in red in figure 2.

The January 2010 earthquake occurred in the Enriquillo Fault Zone, although it is not clear whether it was on the main fault trace that produces major geomorphic features across southern Haiti (Mann and others, 1984). Calais and others (2002) and Manaker and others (2008) determined a slip rate of $7 \mathrm{~mm} / \mathrm{yr}$ for this fault from fitting velocities derived from GPS measurements with a block model that accounts for elastic strain accumulation on locked faults. Based on the fault trace, there is a possible segment boundary at about 73 degrees W longitude, where the fault makes a left, transtensional step (Miragoane basin; Momplaisir, 1986). This location is also the approximate western limit of the rupture zone of the January 2010 earthquake, on the basis of modeling of teleseismic waveforms (Gavin Hayes, USGS, written commun., 2010), as well as the locations of aftershocks. We treat this step as a segment boundary to rupture on the fault. Using the relations of Wells and Coppersmith (1994), the length of the eastern segment of the fault yields a maximum magnitude of 7.7. We also apply this maximum magnitude (also equal to $M_{\text {char }}$ ) to the onshore portion of the fault west of the segment boundary. We treated the offshore portion of the Enriquillo Fault west of Haiti (green trace in figure 2) separately from the rest of the fault. The procedure described above was used to estimate $M_{\text {char }}$ for this portion of the fault and to calculate the hazard. The $M_{\text {char }}$ determined is 7.6.

Based on historical accounts, the large earthquakes of 1751,1770 , and 1860 are inferred to have occurred in the Enriquillo Fault Zone (Kelleher and others, 1973; summary by Ali and others, 2008). Based on the areas of highest intensity, the magnitude of the largest of these earthquakes is thought to have been about M7.5 (see summary in Ali and others, 2008). Therefore, using an $M_{\text {char }}$ and $M_{\max }$ of 7.7 , somewhat larger than that observed historically, for each segment of the Enriquillo Fault is a reasonable approach. Future maps will involve a logic tree for $M_{\text {char }}$ on the faults.

Our model predicts an annual recurrence rate of 0.016 for earthquakes with magnitudes equal to or greater than 6.5 for the onland portion of the Enriquillo Fault (red trace in figure 2; table 1). If we assume that the 1751, 1770, and 1860 earthquakes were all greater than $M 6.5$ and include the 2010 earthquake, the average observed recurrence rate for $M \geq 6.5$ is 0.012 , comparable to the predicted rate.

The mapped fault trace of the Septentrional Fault suggests that there are two major segments for this fault in Hispaniola, (fig. 2). Using the length of the eastern segment, we determined a maximum magnitude of 7.8. We assigned this maximum magnitude to both segments of the fault. We used a slip rate of $12 \mathrm{~mm} / \mathrm{yr}$ for this fault, following the value Calais and others (2002) determined from GPS data. This slip rate is at the upper limit, but compatible with, the $6-12 \mathrm{~mm} /$ yr rate found along the central portion of the fault by Prentice and others (2003) from geologic offsets and trenching. The inferred slip rates of the Enriquillo and Septentrional Faults add to $19 \mathrm{~mm} / \mathrm{yr}$, similar to the total rate of motion of $20 \mathrm{~mm} /$ yr determined for the Caribbean Plate relative to the North American Plate (DeMets and others, 2000). Note that we treat the portion of the Septentrional Fault west of Haiti separately (green trace in figure 2).

For the Septentrional Fault we used a frequencymagnitude distribution in which 67 percent of the moment rate was taken up by characteristic earthquakes and 33 percent of the moment rate was assigned to the truncated GR relation. We found that using a 50/50 split produced a rate of $M \geq 6.5$ earthquakes higher than that observed since 1915. The 67/33 division reduced the predicted rate of $M \geq 6.5$ earthquakes by about 30 percent.

The model predicts an annual rate of earthquakes with $M \geq 6.5$ of 0.021 for the portion of this fault shown in red in figure 2 (see table 1). The catalog shows a few earthquakes with $M \geq 6$ since 1915 that may have been in this fault zone (fig. 1). Large earthquakes in 1842 and 1887 may have occurred on the western portion of the fault (Kelleher and others, 1973; Ali and others, 2008). Based on trenching in the central portion of the Septentrional fault, Prentice and others 
(2003) concluded that $M \geq 7$ earthquakes had about a 1,000year recurrence time at that location. However, earthquakes with magnitudes around 7.0 may not produce sizeable surface displacements that could be observed in trenches, as possibly evidenced by the M7.0 January, 2010, earthquake in Haiti.

We also included the estimated hazard from the Matheux Neiba thrust fault. This fault is one of the thrust faults that underlie the mountain ranges in Haiti (Mann and others, 1995). We used a slip rate of $1 \mathrm{~mm} / \mathrm{yr}$ derived from the upper bound allowed by the current GPS-measured velocity. The only constraint on this slip rate is the lack of significant deformation in the GPS data so far. The trace of the Matheux Neiba Fault has a length of $191 \mathrm{~km}$, corresponding to an $M_{\text {char }}$ of 7.7 from the Wells and Coppersmith (1994) relations. Based on these preliminary parameters, the recurrence time for large earthquakes on this fault is longer than that on the Enriquillo or Septentrional Faults (table 1). However, because this is a thrust fault, we would expect an earthquake on this fault to generate higher ground motions than an earthquake of similar magnitude on the predominantly strike-slip faults (see, for example, Chiou and others, 2008). Geologic investigation of this fault is a high priority because of the large uncertainty in its slip rate and the importance of assessing the hazard from this fault for the areas north of Port au Prince. Much additional work is needed to quantify its level of recent activity. We also note that there are other possible faults in the Plateau Central that are not used in our assessment here. The absence of substantial deformation in the current GPS data for this area provides some information on the upper limit of their slip rates.

\section{Subduction Zones}

Active subduction zones are located off the northern and southeastern coasts of Hispaniola (fig. 2), although it is debated whether the Muertos Trough and accretionary prism in the south have all the characteristics of a subduction zone. The eastern portion of the northern subduction zone produced a sequence of powerful earthquakes from 1946 to 1953. Determinations of the surface wave magnitude of the 1946 earthquake range from 7.8 to 8.1 (see, for example, Dolan and Wald, 1998). Focal mechanisms for these earthquakes indicate southwestward subduction of the North American Plate. We followed the recurrence characterization of this zone used by Mueller and others (2010) in hazard maps for Puerto Rico. We assumed that rupture of this portion of the subduction zone occurred as $M 8.0$ characteristic earthquakes with an average recurrence time of 200 years. Given the area of this portion of the subduction zone, this produces a slip rate of $11 \mathrm{~mm} / \mathrm{yr}$. This slip rate will need to be reevaluated in some areas in light of the motion on the Septentrional Fault.

The subduction zone is thought to continue to the west along the entire north coast of Hispaniola. However, because of the partitioning of slip between the subduction zone and the crustal strike-slip faults, the slip rate of the western portion of the northern Hispaniola subduction zone is probably less than that further to the east. We used a slip rate of $2.5 \mathrm{~mm} / \mathrm{yr}$ for this western portion, as determined from a new analysis of GPS measurements by E. Calais.

We used a frequency-magnitude distribution for interface earthquakes on this western portion of the northern subduction zone. We assumed the maximum magnitude was 8.0, consistent with the magnitude of the 1946 earthquake. We followed a procedure similar to that for the crustal faults. We assigned 50 percent of the moment rate to earthquakes with $M 8.0$ and 50 percent to a Gutenberg-Richter distribution with a minimum magnitude of 7.5. Note that this minimum magnitude is higher than that used for the crustal faults. We found that using a lower minimum magnitude produced a higher rate of earthquakes than observed in the historical record. Recurrence rates derived from this slip rate are listed in table 1. Again the hazard from smaller earthquakes along the subduction zones is captured from the gridded seismicity calculation (see below).

The Muertos Trough subduction zone is located south of Hispaniola and extends eastward to south of Puerto Rico. There is evidence that this zone ruptured in a large earthquake in 1751 that produced a tsunami (McCann, 2006). A M6.7 earthquake in this area in 1984 had a thrust focal mechanism consistent with subduction. The Enriquillo Fault appears to merge into the Muertos Trough or the Neiba thrust fault, although the geometry of that connection is poorly understood. We would expect the $7 \mathrm{~mm} / \mathrm{yr}$ estimated slip rate of the Enriquillo Fault to be taken up along the Muertos Trough subduction zone as some combination of subduction and trench-parallel motion. Therefore, we used a slip rate of $7 \mathrm{~mm} /$ year for the Muertos zone to calculate recurrence rates (table 1). We assumed that the subduction zone is fully coupled. We used a segmentation of the Muertos Trough based on the change of strike of the subduction zone. We applied the same procedure as we did for the western portion of the northern subduction zone, where 50 percent of the moment rate is released in $M 8.0$ earthquakes and 50 percent is released in a Gutenberg-Richter distribution of earthquakes from M6.5 to M8.0.

The model for the Muertos Trough predicts an annual recurrence rate of $M \geq 7.5$ earthquakes of 0.008 when the rates from both segments are added. The last such earthquake on this zone apparently occurred in 1751. However, other large earthquakes in the 1600s may also have occurred in this zone. Thus, it is problematic to assign a long-term rate of large earthquakes on this zone to test the model. The predicted rate could be lowered by increasing $M_{\max }$ for the zone or by giving higher weights to models with larger magnitudes.

\section{Spatially Smoothed Seismicity}

We followed the procedure of Frankel (1995) to calculate the hazard from background shallow earthquakes using the 
spatially smoothed seismicity. Maximum likelihood $a$-values were determined for grid cells 0.1 by 0.1 degrees in latitude and longitude. These seismicity rates were then spatially smoothed using a Gaussian function with a correlation distance of $50 \mathrm{~km}$. This background hazard was calculated for earthquakes between M5.0 and M7.0. We used finite faults with random strikes when determining the hazard from earthquakes greater than M6.0.

First we estimated completeness times for the instrumental catalog using plots of cumulative number of events above a certain magnitude threshold as a function of time. We found that the catalog is approximately complete for M4.0 and larger earthquakes since 1963 and for M6.0 and larger shocks since 1915. These magnitude thresholds were applied when calculating the maximum-likelihood $a$-values for each grid cell.

The seismicity was divided into three depth ranges $(0-40$ $\mathrm{km}, 41-100 \mathrm{~km}, 101 \mathrm{~km}$ and deeper) and a seismicity rate grid was constructed for each depth range. Using earthquakes since 1963, we found a maximum-likelihood b-value of $0.74 \pm 0.07$ for the declustered catalog of earthquakes with depths less than $40 \mathrm{~km}$, as well as for events between 41 and $100 \mathrm{~km}$ depth. Rounding to the nearest 0.05 , we used a b-value of 0.75 in the hazard calculation for all depth ranges.

For the purposes of the hazard calculation, we used a depth to top of rupture of $10 \mathrm{~km}$ for the seismicity rate grid based on earthquakes shallower than $40 \mathrm{~km}$, noting that the number of earthquakes in most locations generally decreases with increasing depth. A depth to top of rupture of $60 \mathrm{~km}$ was specified for the hazard calculation from the seismicity grid of earthquakes between 41 and $100 \mathrm{~km}$. A 120-km depth was used for the hazard calculation for earthquakes deeper than $100 \mathrm{~km}$. Different attenuation relations were applied for the earthquakes of less than 40-km depth and the deeper earthquakes (see section on Attenuation Relations).

\section{Attenuation Relations}

We used the same set of attenuation relations (groundmotion prediction equations) as applied in the western portion of the 2008 version of the U.S. national seismic hazard maps (Petersen and others, 2008). For the three crustal faults and the gridded seismicity at depths less than $40 \mathrm{~km}$, three of the Next Generation of Attenuation (NGA) relations were implemented with equal weighting: Boore and Atkinson (2008), Campbell and Bozorgnia (2008), and Chiou and Youngs (2008). The NGA relations are based on a global compilation of strong ground motion records from tectonically active areas.

For the subduction zones, we used attenuation relations developed specifically for earthquakes on the interface of subduction zones. We applied the same attenuation relations that were used in the 2008 national seismic hazard map for the Cascadia region. These consist of Zhao and others (2006, 1/2 weight), Atkinson and Boore (2003; 1/4 weight), and Youngs and others (1997; 1/4 weight). For the spatially smoothed gridded seismicity for depths greater than $40 \mathrm{~km}$ we used the global intraslab attenuation relations of Atkinson and Boore (2003; $1 / 2$ weight) and the intraslab attenuation relations of Youngs and others (1997; 1/2 weight).

Maps were also constructed that contain site amplification. Here we used a grid of Vs30 values provided by David Wald (USGS) that were determined from the topographic slope on a 1-km grid using the method of Wald and Allen (2007). The site-amplification factors were included within the hazard integral. The NGA relations contain nonlinear amplification factors as a function of Vs30. For the attenuation relations for subduction-zone earthquakes and the intraslab earthquakes, we applied the nonlinear amplification factors of Boore and Atkinson (2008) to the firm-rock values. These nonlinear amplification factors are dependent on the peak ground acceleration calculated for a rock reference site.

\section{Results}

Our initial seismic hazard maps for a firm-rock site condition are shown in figures 3 and 4 . These maps are based on the assumption that earthquake occurrence is Poissonian (time independent). The maps do not include the hazard from aftershocks. These maps are for peak horizontal ground accelerations (PGA; percent $g$ ) for 10 percent and 2 percent probabilities of exceedance (PE) in 50 years, respectively.

The hazard maps show that there is substantial earthquake hazard throughout Haiti and the Dominican Republic. The map with 10-percent PE in 50 years exhibits the highest hazard around the northeastern subduction zone, the Muertos subduction zone, and the Septentrional and Enriquillo Faults. The maps with 2-percent PE in 50 years also show high hazard along the Matheux Neiba Fault Zone. The hazard from this fault is more prominent on the map of 2-percent PE in 50 years than on the map of 10-percent PE in 50 years because it has a relatively long estimated recurrence time of about 300 years for earthquakes with $M \geq 6.5$ (table 1).

A map with the grid of Vs30 values derived from topographic slope is shown in figure 5 (David Wald, written commun., 2010). The grid spacing is about $1 \mathrm{~km}$. For this region, soils generally have Vs 30 values less than $400 \mathrm{~m} / \mathrm{s}$. We used this Vs30 grid to calculate nonlinear site-amplification factors for the attenuation relations.

Figure 6 depicts the maps of 10-percent and 2-percent $\mathrm{PE}$ in 50 years with site amplification. Areas of soil have higher ground motions than the corresponding locations in the rock-site maps. For example, the area of Port au Prince and the Enriquillo Valley has increased hazard relative to its value on the rock-site maps. Other prominent areas of elevated hazard compared to the rock-site maps include the Cibao and San Juan Valleys in the Dominican Republic and the Artibonite River Valley north of Saint-Marc, Haiti. However, care should be taken when using these maps with site amplification, 
because site-specific information should be used whenever possible. Also, the Vs30 values assigned to the lowlands from the topography are estimates and need to be evaluated with geological and geophysical fieldwork.

These hazard maps represent our initial attempt at characterizing the ground-shaking hazard from future earthquakes in Haiti. As the results of further geologic and geophysical fieldwork in Haiti become available, there will be more information on the slip rates and earthquake chronologies for the active faults and subduction zones. These data will improve the estimation of seismic hazard for Haiti.

\section{Acknowledgments}

This work was partially supported by the U.S. Agency for International Development (USAID), as a component of the USGS/USAID Earthquake Disaster Assistance Team (EDAT). We thank Mark Petersen and Craig Weaver for their valuable reviews that helped to improve this report. David Wald provided the grid of Vs30 values for Hispaniola. Tom Brocher made useful comments on the report.

\section{References Cited}

Ali, S.T., Freed, A.M., Calais, E., Manaker, D.M., and McCann, W.R., 2008, Coulomb stress evolution in northeastern Caribbean over the past 250 years due to coseismic, postseismic, and interseismic deformation: Geophysical Journal International, v. 174, p. 904-918.

Atkinson, G.M., and Boore, D.M., 2003, Empirical groundmotion relations for subduction-zone earthquakes and their application to Cascadia and other regions: Bulletin of the Seismological Society of America, v. 93, p.1703-1729.

Boore, D.M., and Atkinson, G.M., 2008, Ground-motion prediction equations for the average horizontal component of PGA, PGV, and 5\%-damped PSA at spectral periods between $0.01 \mathrm{~s}$ and $10.0 \mathrm{~s}$ : Earthquake Spectra, v. 24, p. 99-138.

Calais, E., Mazabraud, Y., Mercier de Lepinay, B., Mann, P., Mattioli, G., and Jansma, P., 2002, Strain partititioning and fault slip rates in the northeastern Caribbean from GPS measurements: Geophysical Research Letters, v. 29, doi:10.1029/2002GL015397.

Campbell, K.W., and Bozorgnia, Y., 2008, NGA ground motion model for the geometric mean horizontal component of PGA, PGV, PGD and 5\% damped linear elastic response spectra for periods ranging from 0.01 to $10 \mathrm{~s}$ : Earthquake Spectra, v. 24, p. 139-172.
Chiou, B.S.J., and Youngs, R.R., 2008, Chiou-Youngs NGA ground motion relations for the geometric mean horizontal component of peak and spectral ground motion parameters: Earthquake Spectra, v. 24, p. 1716.

DeMets, C., Jansma, P.E., Mattioli, G.S., Dixon, T.H., Farina, F., Bilham, R., Calais, E., and Mann, P., 2000, GPS geodetic constraints on Caribbean-North America plate motion: Geophysical Research Letters, v. 27, p. 437-441.

Dolan, J.F., and Wald, D.J., 1998, The 1943-1953 north-central Caribbean earthquakes; active tectonics setting, seismic hazards, and implications for Caribbean-North America plate motions, in Dolan, J.F., and Mann, P., eds., Active strike-slip and collisional tectonics of the northern Caribbean plate boundary zone: Geological Society of America Special paper 326, p. 143-170.

Engdahl, E.R., and Villasenor, A., 2002, Global seismicity-1900-1999, in Lee, W.H.K., Kanamori, H., Jennings, P.C., and Kisslinger, C., eds., International handbook of earthquake and engineering seismology: International Association of Seismology and Physics of the Earth's Interior (IASPEI), p. 665-690.

Frankel, A.D., 1995, Mapping seismic hazard in the central and eastern United States: Seismological Research Letters, v. 66, p. $8-21$.

Frankel, A., Mueller, C., Barnhard, T., Leyendecker, E., Wesson, R., Harmsen, S., Klein, F., Perkins, D., Dickman, N., Hanson, S., and Hopper, M., 2000, USGS national seismic hazard maps: Earthquake Spectra, v. 16, p. 1-19.

Frankel, A., Petersen, M., Mueller, C., Haller, K., Wheeler, R., Leyendecker, E., Wesson, R., Harmsen, S., Cramer, C., Perkins, D., and Rukstales, K., 2002, Documentation for the 2002 update of the national seismic hazard maps: U.S. Geological Survey Open-File Report 02-420, 39 p.

Kelleher, J., Sykes, L., and Oliver, J., 1973, Possible criteria for predicting earthquake locations and their application for major plate boundaries of the Pacific and the Caribbean: Journal of Geophysical Research, v. 78, p. 2547-2585.

Manaker, D.M., Calais, E., Freed, A.M., Ali, S.T., Przybylski, P., Mattioli, G., Jansma, P., Prepetit, C., and de Cahbalier, J.B., 2008, Interseismic plate coupling and strain partitioning in the northeastern Caribbean: Geophysical Journal International, v. 174, p. 889-903, doi:10.1111/j.1365-246X $.2008 .03819 \mathrm{x}$.

Mann, P., Burke, K., and Matumoto, T., 1984, Neotectonics of Hispaniola; plate motion, sedimentation, and seismicity at a restraining bend: Earth Planetary Science Letters, v. 70, p. $311-324$. 
Mann, P., Taylor, F.W., Edwards, R.L., and Ku, T-L, 1995, Actively evolving microplate formation by oblique collision and sideways motion along strike-slip faults; an example from the northeastern Caribbean plate margin: Tectonophysics, v. 246, p. 1-69.

McCann, W.R., 2006, Estimating the threat of tsunamagenic earthquakes and earthquake induced landslide tsunamis in the Caribbean, in Aurelio, M., and Philip, L., eds., Caribbean tsunami hazard: Singapore, World Scientific Publishing, p. $43-65$.

Momplaisir, R., 1986, Contribution à l'étude géologique de la partie orientale du massif de la Hotte (Presqu'Ile du Sud d'Haiti), synthèse stucturale des marges de la Presqu'Ile du Sud à partir de données sismiques: University of Paris VI, Ph.D. dissertation.

Mueller, C., Hopper, M., and Frankel, A., 1997, Preparation of earthquake catalogs for the national seismic hazard maps: U.S. Geological Survey Open-File Report 97-464, 36 p.

Mueller, C., Frankel, A., Petersen, M., and Leyendecker, E., 2010, New seismic hazard maps for Puerto Rico and the U.S. Virgin Islands: Earthquake Spectra, v. 26, p. 169-186.
Petersen, M., Frankel, A., Harmsen, S., Mueller, C., Haller, K., Wheeler, R., Wesson, R., Zeng, Y., Boyd, O., Perkins, D., Luco, N., Field, E., Wills, C., and Rukstales, K., 2008, Documentation for the 2008 update of the United States national seismic hazard maps: U.S. Geological Survey Open-File Report 2008-1128, 61 p.

Prentice, C.S., Mann, P., Pena, L.R., and Burr, G., 2003, Slip rate and earthquake occurrence along the central Septentrional fault, North American-Caribbean plate boundary, Dominican Republic : Journal of Geophysical Research, v. 108, no. B3, doi:10.1029/2001JB000442.

Wald, D.J., and Allen, T.I., 2007, Topographic slope as a proxy for seismic site conditions and amplification: Bulletin of the Seismological Society of America, v. 97, p. 1379-1395.

Wells, D.L., and Coppersmith, K.J., 1994, New empirical relationships among magnitude, rupture length, rupture width, rupture area, and surface displacement: Bulletin of the Seismological Society of America, v. 84, p. 974-1002.

Youngs, R.R., Chiou, S.-J., Silva, W.J., and Humphrey, J.R., 1997, Strong ground motion attenuation relationships for subduction zone earthquakes: Seismological Research Letters, v. 68 , p. $58-73$. 
Table 1. Parameters for crustal faults and subduction zones, Hispaniola region.

\begin{tabular}{lccccc}
\hline \multicolumn{1}{c}{ Crustal fault or subduction zone } & $\begin{array}{c}\text { Slip rate } \\
(\mathbf{m m} / \mathbf{r r})\end{array}$ & $\boldsymbol{M}_{\text {char }}$ & $\boldsymbol{M}_{\text {min }}$ & $\begin{array}{c}\text { Predicted Annual Rate } \\
\boldsymbol{M} \geq \mathbf{6 . 5}\end{array}$ & $\begin{array}{c}\text { Predicted Annual Rate } \\
\boldsymbol{M} \geq \mathbf{7 . 0}\end{array}$ \\
\hline Enriquillo & 7 & 7.7 & 6.5 & 0.016 & 0.0053 \\
Septentrional & 12 & 7.8 & 6.5 & 0.021 & 0.0078 \\
Matheux Neiba & 1 & 7.7 & 6.5 & 0.0034 & 0.0012 \\
Eastern and central portions of northern subduction zone & 11 & 8.0 & 8.0 & 0.005 & 0.005 \\
Western portion of northern subduction zone & 2.5 & 8.0 & 7.5 & 0.00088 & 0.00088 \\
Muertos Trough subduction zone, Neiba segment & 7 & 8.0 & 7.5 & 0.0030 & 0.0030 \\
Muertos Trough subduction zone central segment & 7 & 8.0 & 7.5 & 0.0050 & 0.0050 \\
\hline
\end{tabular}

haiti catalog (1900-Feb2010,M>4,declustered) (EVC+PDE+ISC)

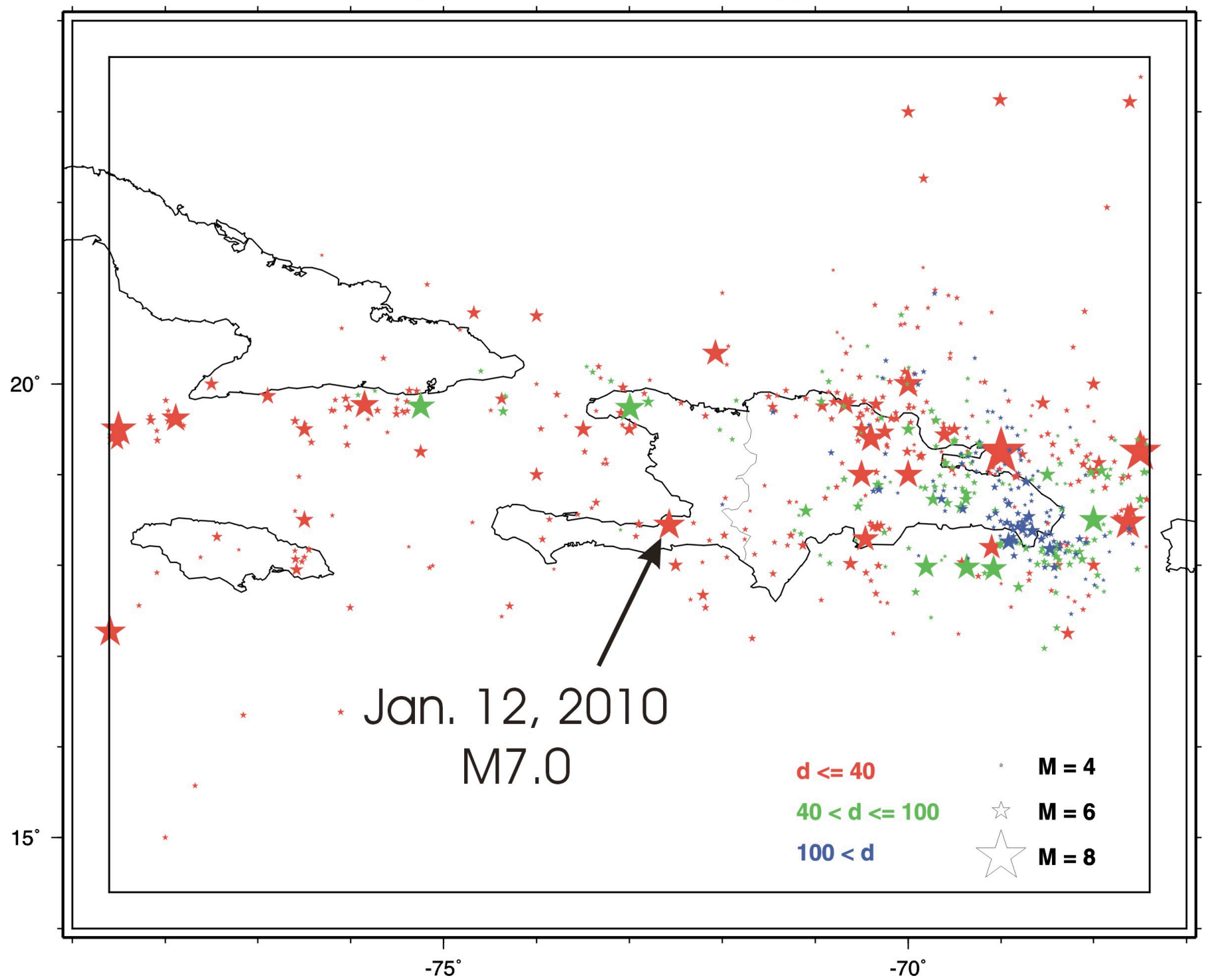

Figure 1. Seismicity for the Hispaniola region for the time period 1900-2010. Dependent earthquakes (for example, aftershocks and foreshocks) are not shown. The earthquakes are grouped into three categories by depth (d) of hypocenter, and their magnitudes are indicated by the size of the symbols. 


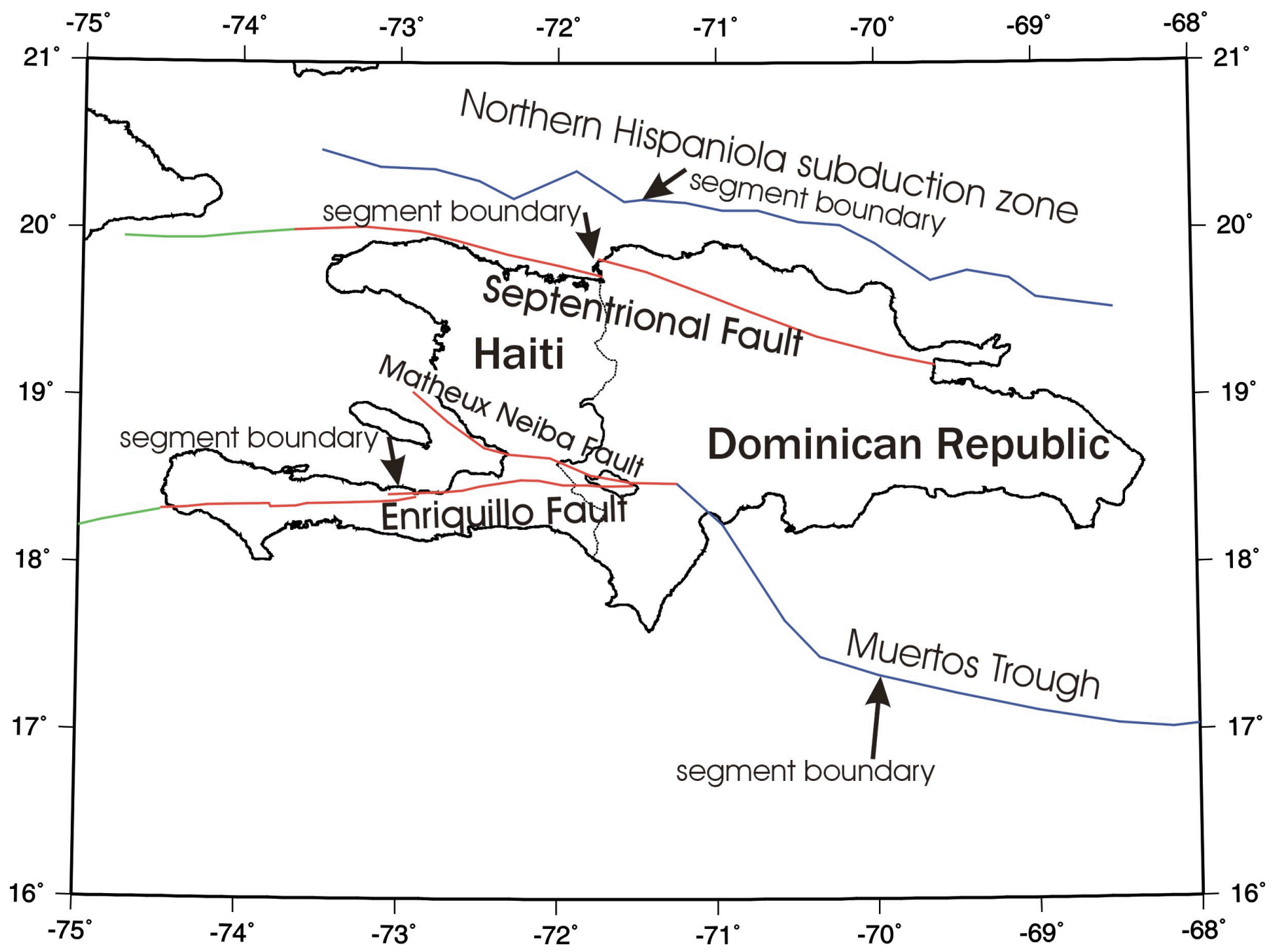

Figure 2. Crustal faults and subduction zones used in the hazard maps. Red lines denote the portions of the Septentional and Enriquillo Faults used to calculate $M_{\text {char }}$ and whose predicted earthquake rates are shown in table 1. Green lines denote the western portions of the Septentrional and Enriquillo Faults that are treated separately. Blue lines denote the traces of the uppermost portion of the subduction zone faults considered. Locations of the inferred segment boundaries used in the hazard maps are marked by arrows. 


\section{PGA (\%g) with 10\% Probability of Exceedance in 50 Years}

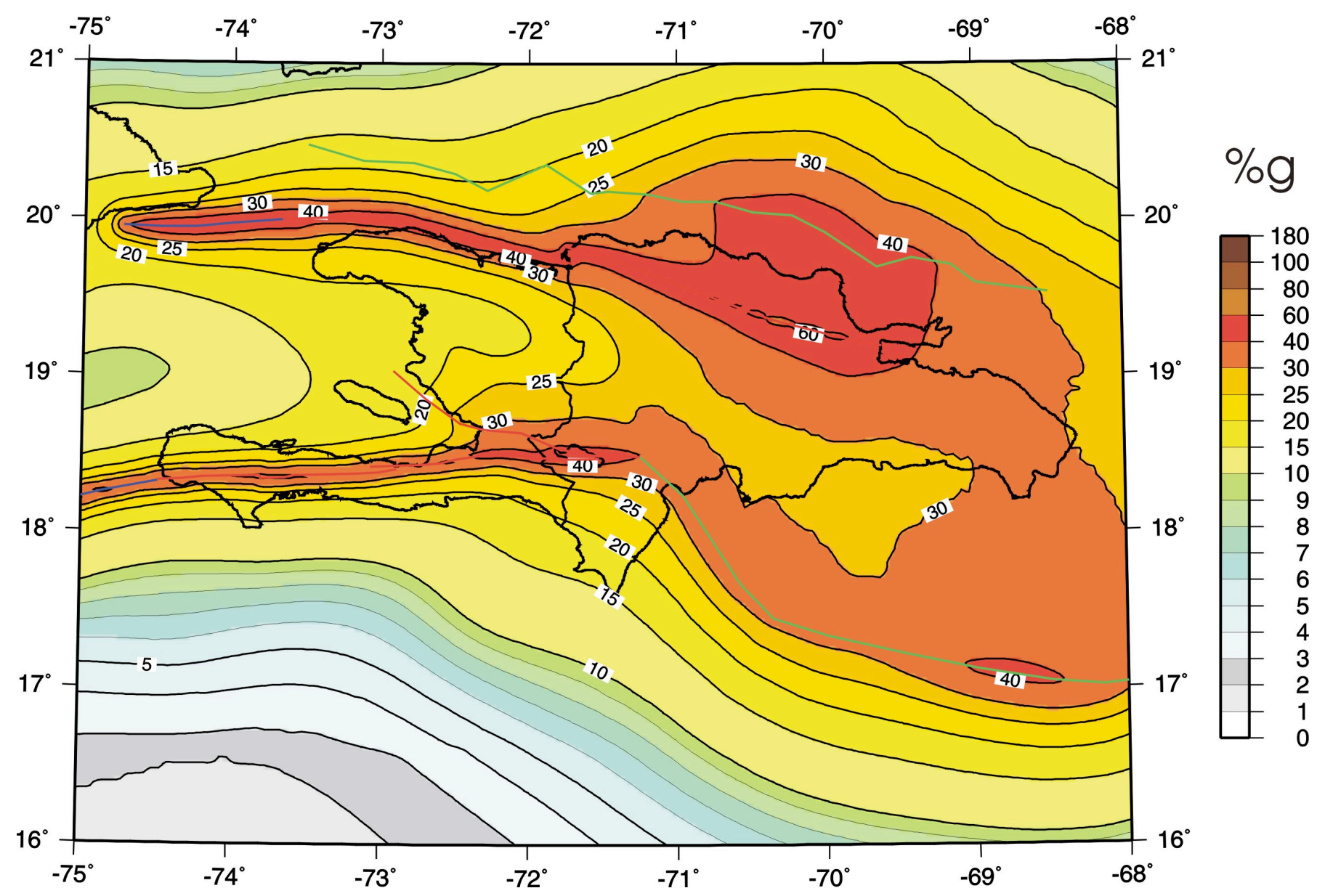

Figure 3. Seismic hazard map of Hispaniola region with peak ground acceleration (PGA; in $\% g$ ) having 10 percent probability of exceedance in 50 years, without aftershock hazard. Fault and subduction zone traces are shown as in figure 2. 


\section{PGA (\%g) with $2 \%$ Probability of Exceedance in 50 Years}

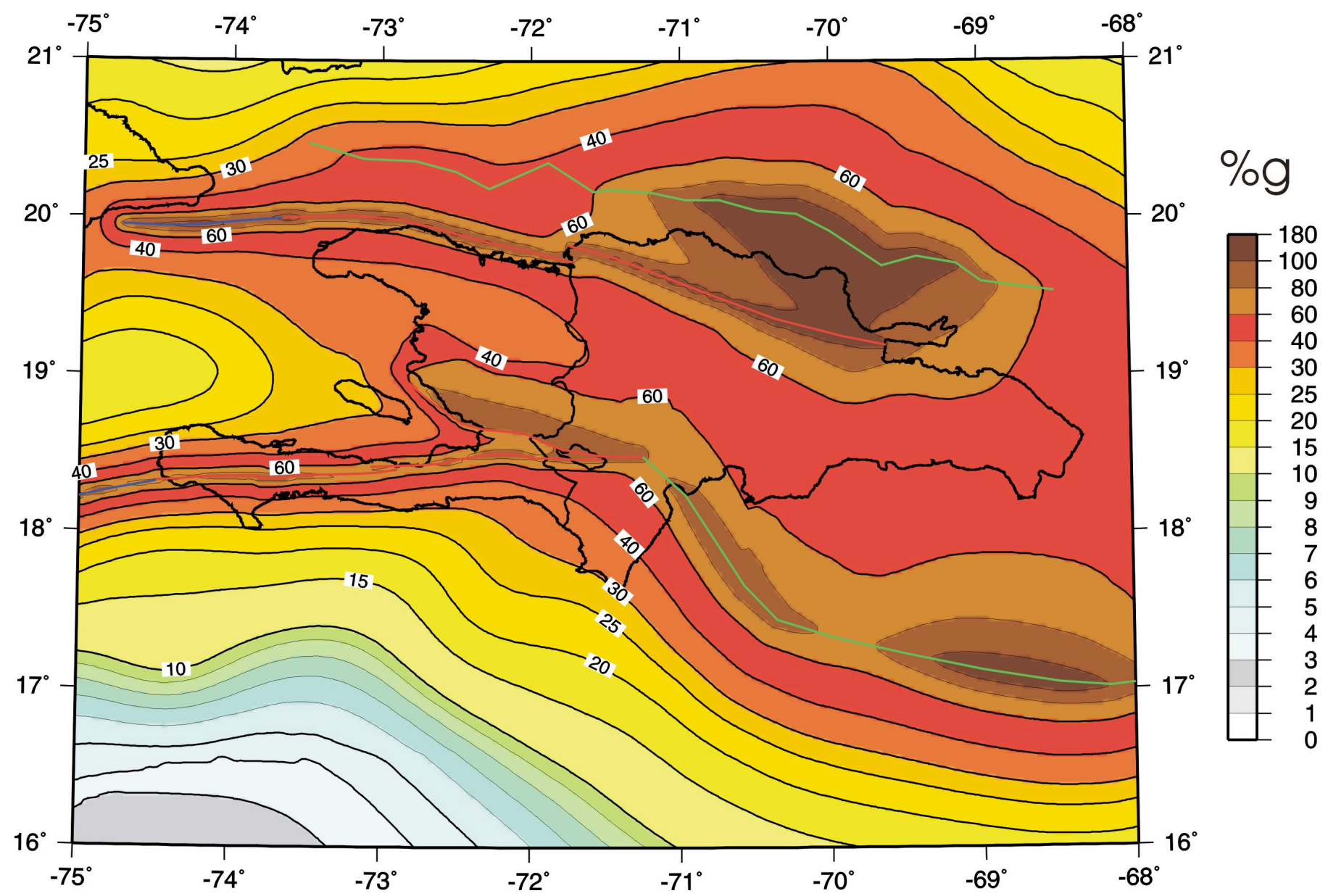

Figure 4. Seismic hazard map of Hispaniola region with PGA $(\% g)$ having 2 percent probability of exceedance in 50 years $(1$ in 2,500 annual probability of exceedance), without aftershock hazard. Fault and subduction zone traces are shown as in figure 2. 


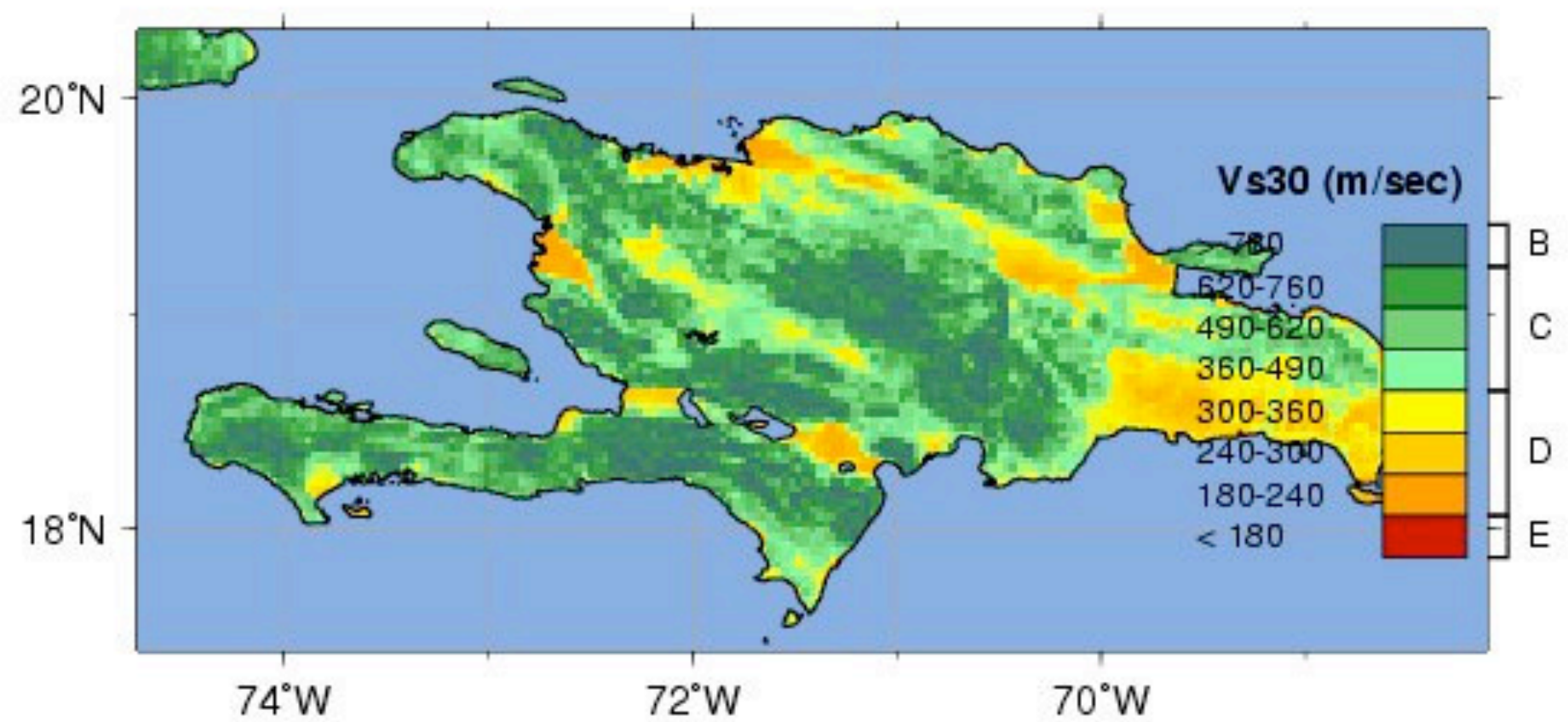

Figure 5. Map of Hispaniola showing shear-wave velocity averaged over the top $30 \mathrm{~m}$ of the ground (Vs30) derived from topographic slope. Letters to the right of color scale indicate NEHRP site classes. Figure provided by David Wald, USGS. 


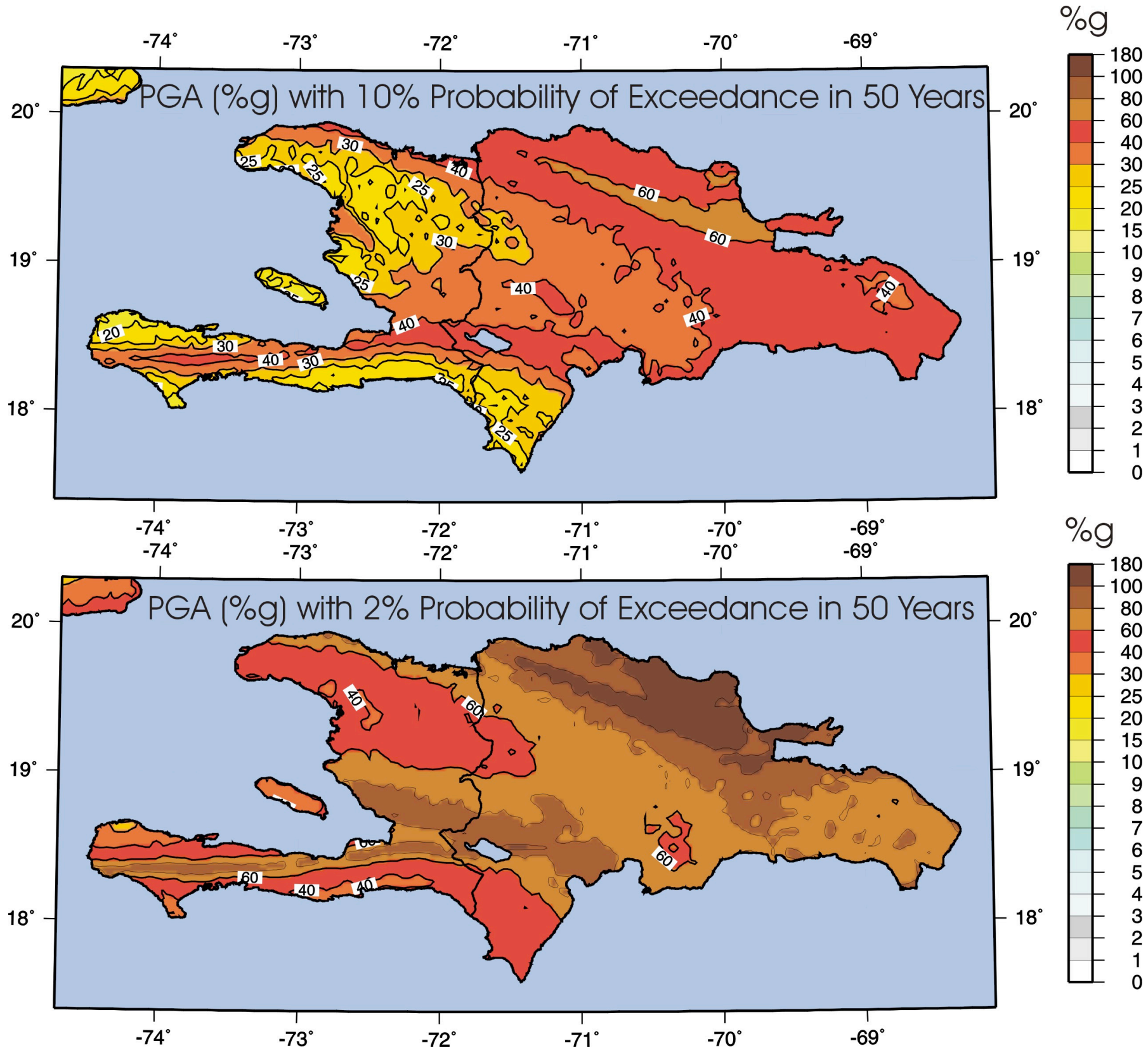

Figure 6. Seismic hazard maps of Hispaniola using site amplification based on Vs30 grid in figure 5. Maps show PGA (\%g) with (top) 10 percent and (bottom) 2 percent probabilities of exceedance in 50 years (without aftershock hazard). Irregular north-south line is boundary between Haiti (left) and the Dominican Republic (right). 
This page intentionally left blank 


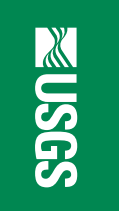

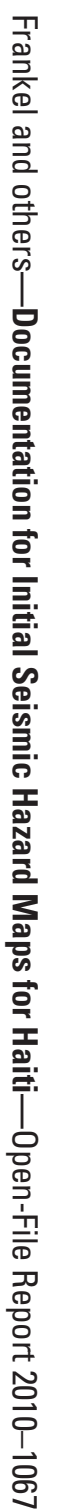

